\title{
The Ecological Management Projects of Cyanobacteria Bloom and the Effects in Jiuquwan Reservoir
}

\author{
Huan LUO \\ Pearl River Hydraulic Research Institute of PRWRC \\ Guangzhou 510611, China \\ e-mail: gzluohuan@163.com \\ Jinrun HU \\ Pearl River Hydraulic Research Institute of PRWRC \\ Guangzhou 510611, China \\ e-mail: 363901487@qq.com
}

\author{
Wenlong CHEN \\ Pearl River Hydraulic Research Institute of PRWRC \\ Guangzhou 510611, China \\ e-mail: 48708209@qq.com \\ Qiong WU \\ Pearl River Hydraulic Research Institute of PRWRC \\ Guangzhou 510611, China \\ e-mail: wq_hhu@163.com
}

\begin{abstract}
Jiuquwan Reservoir is the only drinking water source supplied for Xunwu county residents. It is located in the middle reaches of Mati River belongs to the East River upstream tributary of the Pearl River basin. The ecological management projects of cyanobacteria bloom in Jiuquwan Reservoir was described. And the influence of ecological projects of the reservoir for algae and other biological compositions and nutrient levels was analyzed. The results showed that the ecological management projects played an active role in management cyanobacteria bloom and eutrophication and had played a positive role in the optimization of water ecosystem. These projects have had desired ecological effects in Jiuquwan Reservoir.
\end{abstract}

Keywords-cyanobacteria bloom; Jiuquwan Reservoir; ecological management projects

\section{INTRODUCTION}

Reservoir water is an important source of drinking water for residents. While China has nearly one-third of important drinking water reservoirs in the eutrophication status, and some important large drinking water reservoirs such as Miyun Reservoir in Beijing[1], Qiaodun Reservoir in Wenzhou[2], Nanwan Reservoir in Xinyang[3] and Hedi Reservoir in Guangdong[4] had a serious outbreak of cyanobacteria blooms ever. The problem of eutrophication is growing by increased nutrients and deterioration of water quality then cyanobacteria blooms exposed, especially in the drinking water reservoirs. The outbreak of cyanobacteria bloom directs threated to people's safety of drinking water[5].

The water quality requirements of reservoir for source of drinking water and the specific environmental conditions have restricted the management projects of cyanobacteria bloom. In this situation, the ecological and environmental protection in general and reduction of nutrient inputs are the important treatments in the reservoir eutrophication prevention measures. There require management measures do not produce secondary pollution and environmental damage.

Therefore, according to pollution emissions, physical structure, dispatching status, status of water quality, aquatic biological components and other factors of the reservoir, we follow ecological management engineering principles, using bio-eco-technological methods to control the cyanobacteria bloom in Jiuquwan Reservior.

\section{RESERVOIR OVERVIEW}

Jiuquwan Reservoir is the only drinking water source of water supply for Xunwu county residents. It is located in the middle reaches of Mati River belongs to the East River upstream tributary of the Pearl River basin. Total capacity of reservoir is 4.15 million $\mathrm{m}^{3}$, the surface area of reservoir is $250000 \mathrm{~m}^{2}$ and the average depth of reservoir is $9.52 \mathrm{~m}$. The comprehensive benefits of the reservoir have both flood control and power generation, in addition to the drinking water reservoir.

\section{A. Upstream Pollution Sources}

The point source pollution to Jiuquwan Reservoir is mainly fertilizer and pesticide pollutants. The upstream area of the reservoir has been planted fruit trees 37000 acres. The problems of forest vegetation damage, water conservation function decline, soil erosion are caused by the cultivation of fruit trees are the important reason of agricultural nonpoint source pollution. According to survey results, the storage capacity of chemical oxygen demand(COD), total nitrogen (TN) and total phosphorus (TP) of fertilizer calculated in pure discount $418 \mathrm{t} / \mathrm{a}, 63.4 \mathrm{t} / \mathrm{a}$ and 11.89t/a respectively. Point pollution sources are mainly rural sewage. The sewage flow of rural life in 2011 is $340100 \mathrm{~m}^{3}$ in reservoir catchment area. There was a total about $68000 \mathrm{~m}^{3}$ sediment deposited from July 2005 to January 2014, and annual deposition about $8000 \mathrm{~m}^{3}$.

\section{B. Physical Structure}

Jiuquwan Reservoir is a canyon-shaped river reservoir. The reservoir surface area is $250000 \mathrm{~m}^{2}$ in normal water level, and with an average depth of $9.52 \mathrm{~m}$. The average annual runoff of the reservoir in dam is 67.17 million $\mathrm{m}^{3}$, the annual flow $2.16 \mathrm{~m}^{3} / \mathrm{s}$, peak flow $744 \mathrm{~m}^{3} / \mathrm{s}$, checking peak 
flow $1030 \mathrm{~m}^{3} / \mathrm{s}$. The reservoir belongs to the weakly stratified or layered mixed reservoir judged by water temperature hierarchical model. The annual average number of the reservoir water changing is 28.22 times/a based on the ratio of the average annual runoff and reservoir effective storage capacity. In addition, the narrow structure, a high number of water changes in the reservoir and no large tributary of lake branch and the like on both sides of the steep slope often lead to large fish and other creatures hard to survive. It resulted there is no more big biological biomass in the reservoir area. This is not benefit to biological reproduction and cyanobacteria bloom management.

\section{Dispatching Operation}

The bottom elevation height of discharging bottom holes of Jiuquwan Reservoir is $324.0 \mathrm{~m}$, it has been built to run for many years. In the case where to protect the safety of the building opens the discharging bottom holes to drain would slow down the hazards on water quality and aquatic ecosystems by the siltation of reservoirs and accumulated pollutants. According to operation information of Jiuquwan Reservoir from January 1, 2010 to January 15, 2014 analysis, it within three years of running time, the cumulative frequency of $8.4 \%$ that the water level below $347 \mathrm{~m}$, but overfill or high water over 352 m only $6.6 \%$.

\section{WATER QUALITY}

The 15 water quality indicators were monitored from May 2012 to November 2013. The average of the remaining water quality indicators has reached the multiple standards Class II of "Surface Water Environmental Quality Standard" (GB8383-2002) except the TN and TP. The average value of TN and TP exceed the standard 1.53 and 0.81 times respectively (Fig. 1).
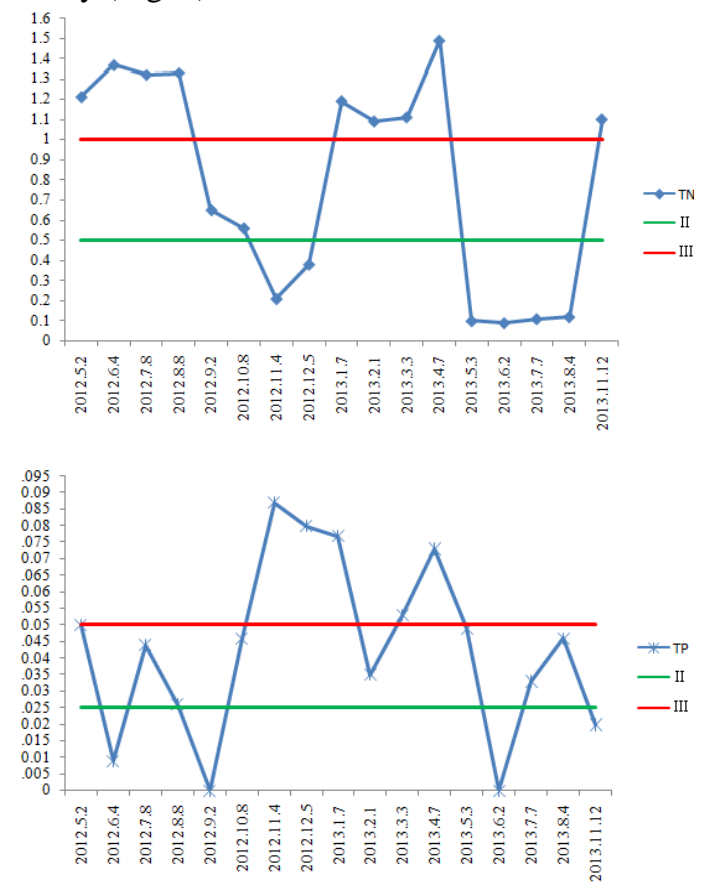

Figure 1. The changes of TN and TP in Jiuquwan Reservoir.

\section{A. Aquatic Biological Components}

The phytoplankton in Jiuquwan Reservoir was total 83 species belonged to 7 phylums. They included 34 species of chlorophyta (accounted for $41 \%$ of the total number of species, the same below); 28 species of diatom (34\%); 11 species of cyanophyta (13\%); 3 species of dinoflagellate (4\%); cryptophyta, chrysophyta and euglenophyta accounted for $2 \%, 2 \%$ and $4 \%$ respectively of the total number of species (Fig. 2).

The zooplankton in Jiuquwan Reservoir was total 53 species. Which the maximum number of species of rotifer, detected 29 species ( $55 \%$ ); followed by protozoa, 15 species, accounted for $28 \%$ of the total number of species.; copepods, 6 species, $11 \%$ of the total number of species; in addition, there were also 5 species in other groups of zooplankton, they were nematodes, polychaete larvae and water bear (Fig. $3)$.

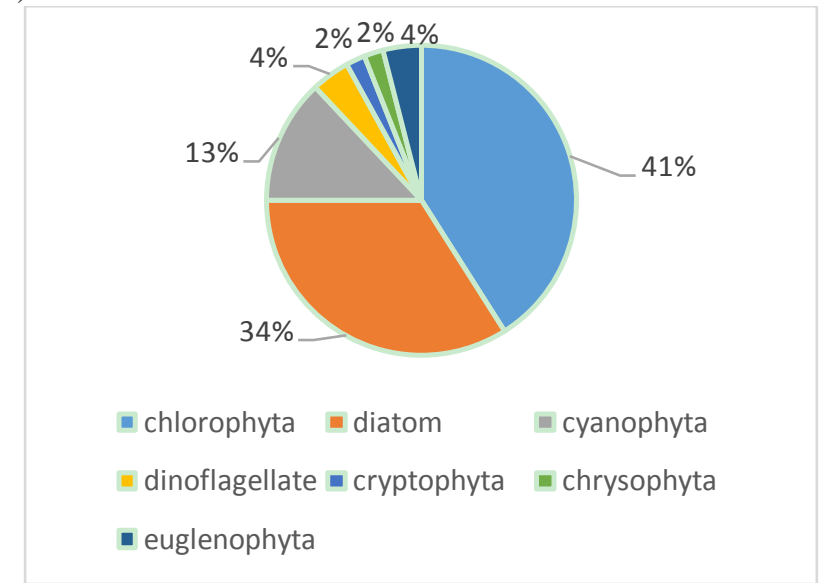

Figure 2. The proportion of phytoplankton species in Jiuquwan Reservoir.

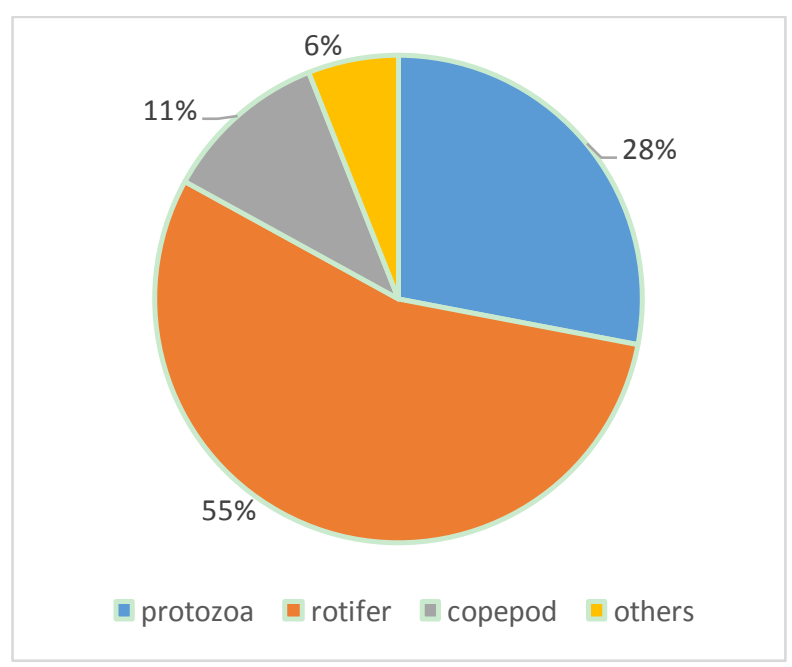

Figure 3. The proportion of zooplankton species in Jiuquwan Reservoir.

The benthic animal in Jiuquwan Reservoir was total 20 species of 3 categories, which 9 species molluscs (45\%), 6 species aquatic insects $(30 \%)$ and 5 species annelida (25\%) (Fig. 4). 
The swimming animal in Jiuquwan Reservoir was 11 species of 9 genera of 3 families of 3 categories. There were 9 species fish (82\%),1 species shrimp (9\%) and1 species reptiles (9\%), nocrabs had been caught (Fig. 5).

There were 6 species large aquatic plants Miscanthussacchariflorus, Phragmitesaustralis, Arundodonax, Cortaderiaselloana, Colocasiagigantea, Nephrolepisauriculata in Jiuquwan Reservoir. These aquatic plants mainly distributed in the middle and tail of the reservoir, and the area before the dam had less abundant. The vegetation or topsoil humus layer of the hydro-fluctuation belt of the reservoir had been seriously eroded.

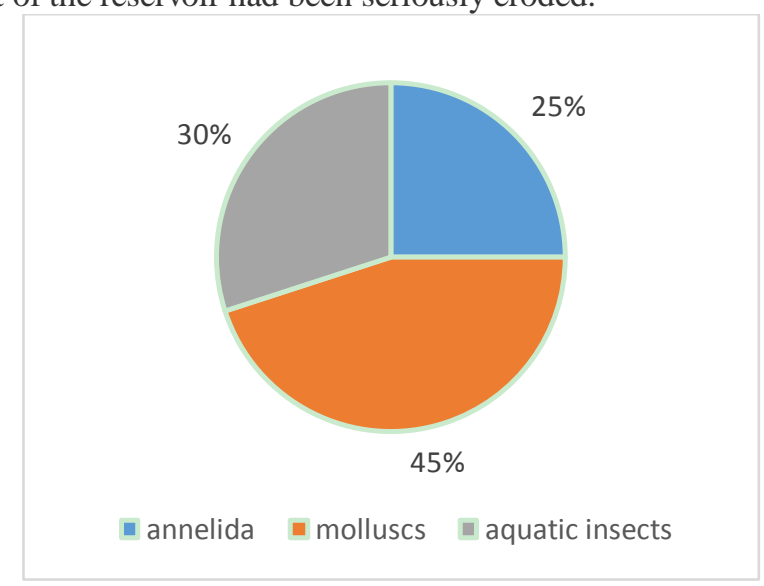

Figure 4. The proportion of benthic animal species in Jiuquwan Reservoir.

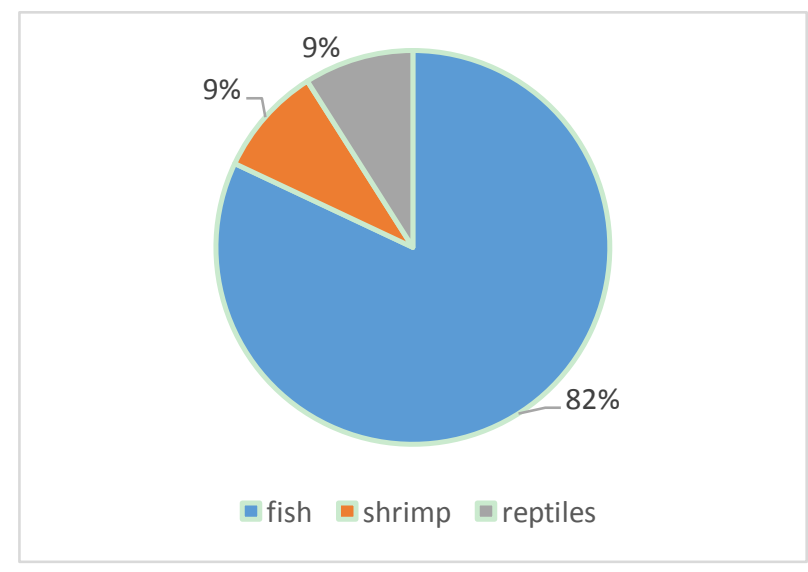

Figure 5. The proportion of swimming animal species in Jiuquwan Reservoir.

\section{B. Cyanobacteria Bloom And Water Quality Condition}

Since 2009, Jiuquwan Reservoir continued outbreak cyanobacteria blooms. The algae outbreak time was generally between April to October, and July, August and September were the most seriously period that whole reservoir would be covered.

The 2014 cyanobacteria bloom covered the whole reservoir and the average density of algal cell was $9051 \times$ $10^{4}$ cells/L. The composition of algae in that bloom was mainly cyanophyta, accounting for $96.7 \%$. In the cyanobacteria bloom period, the average annual total nitrogen of reservoir water was $1.26 \mathrm{mg} / \mathrm{L}$, the highest value was $1.49 \mathrm{mg} / \mathrm{L}$. The annual average total phosphorus was $0.045 \mathrm{mg} / \mathrm{L}$, the highest value was $0.087 \mathrm{mg} / \mathrm{L}$. The annual average ammonia was $0.11 \mathrm{mg} / \mathrm{L}$, the highest value was 0.2 $\mathrm{mg} / \mathrm{L}$. The annual average of COD was $5.7 \mathrm{mg} / \mathrm{L}$, the highest value was $12 \mathrm{mg} / \mathrm{L}$; the annual average of $\mathrm{BOD}_{5}$ was 2.4 $\mathrm{mg} / \mathrm{L}$, the highest value was $3.5 \mathrm{mg} / \mathrm{L}$.

\section{METHODS}

According to current situation of Jiuquwan Reservoir, this paper argued the cyanobacteria bloom management projects mainly measured by the following five aspects:

\section{A. Water Source Protection Engineering Planning}

Through the implementation water source protection project to reduce or control the amount of total nitrogen and total phosphorus of the area source and point source in the watershed.

\section{B. Ecological Restoration Project Pre-Reservoir}

The engineering of pre-reservoir could reduce the amount of pollutants and nitrogen into the reservoir, as well as provide large aquatic animals and plants proliferation germplasm in the reservoir area.

\section{Facilities And Equipments of Pollutants Interceptor Projects}

It can clear the water hyacinth and other floating debris from upstream before they entered the main reservoir area through pollutants Interceptor net and raking after the pre-reservoir. Thus further improve water quality and prevent secondary pollution of water.

\section{Biological And Ecological Restoration Projects in Reservoir Area}

It would improve habitat environment, structure and function of reservoir area through biological and ecological integrated remediation projects. Then it creates suitable living space and environmental quality for large aquatic plants and animals, promotes them growth and reproduction rapidly. And thus projects restrain and deter the bloom breaking.

\section{E. Prevention Project Avoids Fish Escape or Leakage before Dam}

It could prevent fish escape or leakage when reservoir operates by increased fish-block facilities. Though the projects to eradicate imbalances ecosystem structure caused by biological loss and prevent a vicious cycle of aquatic ecosystems.

\section{V.RESULTS}

\section{A. Water Quality Indicators}

Water quality status of Jiuquwan Reservoir has improved after ecological control. Wherein, the concentration of Biochemical Oxygen Demand($\left(\mathrm{BOD}_{5}\right)$, total nitrogen, total phosphorus had decreased significantly, and the average 
concentration of total nitrogen, total phosphorus had decreased $40 \sim 50 \%$ than before (Tab.I). But, $\mathrm{pH}$, dissolved oxygen (DO), COD, ammonia nitrogen $\left(\mathrm{NH}_{3}-\mathrm{N}\right)$ did not change significantly. Probably because these indicators concentration was already low, or they had been the class I or II of the national surface water environmental water quality standard. In addition, the concentration of total nitrogen, total phosphorus decreased so much also may be related to the decrease of point sources and nonpoint pollution from the upstream region.

Because of the decreased of algal cell density, water clarity was also increased significantly. Based on on-site measured data of reservoir cross section, the water transparency was $1.45 \mathrm{~m}$ in July 2015 compared with July 2014's $0.68 \mathrm{~m}$ had increased $113 \%$.

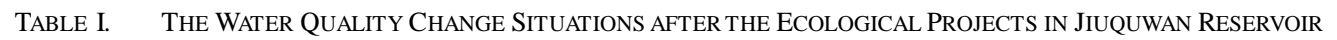

\begin{tabular}{|c|c|c|c|c|c|c|c|}
\hline \multirow{2}{*}{ Indicators } & \multicolumn{3}{|c|}{$2012-2013$} & \multicolumn{3}{|c|}{2015} & \multirow{2}{*}{$\begin{array}{c}\text { Water quality } \\
\text { class }\end{array}$} \\
\hline & mean & $\max$ & $\min$ & mean & $\max$ & $\min$ & \\
\hline $\mathrm{pH}$ & 7.5 & 8.5 & 7.1 & 7.34 & & & I, II \\
\hline $\mathrm{DO}(\mathrm{mg} / \mathrm{L})$ & 7.5 & 10 & 5.8 & 6.7 & & & I, II \\
\hline $\mathrm{COD}(\mathrm{mg} / \mathrm{L})$ & 5.7 & 12 & 2.3 & $<10$ & & & I, II \\
\hline $\mathrm{BOD}_{5}(\mathrm{mg} / \mathrm{L})$ & 2.4 & 3.5 & 2 & 1.6 & & & I, II \\
\hline $\mathrm{NH}_{3}-\mathrm{N}(\mathrm{mg} / \mathrm{L})$ & 0.11 & 0.2 & 0.05 & 0.14 & 0.33 & 0.05 & I, II \\
\hline $\mathrm{TN}(\mathrm{mg} / \mathrm{L})$ & 1.26 & 1.49 & 1.11 & 0.65 & 1.65 & 0.48 & III \\
\hline $\mathrm{TP}(\mathrm{mg} / \mathrm{L})$ & 0.045 & 0.087 & 0.009 & 0.024 & 0.041 & 0.012 & II, III \\
\hline
\end{tabular}

\section{B. Changes of Phytoplankton}

Excessive growth of phytoplankton, particularly blue-green algae blooms and high density are the main causes to deteriorate water quality in Jiuquwan Reservoir. Thus, management and restraint excessive growth and the outbreak algae were the construction of goals, objectives and priorities of the present project.

Algae density in Jiuquwan Reservoir is generally low in winter and spring, and cyanobacteria blooming in summer. So, according to the monitoring data in Jiuquwan Reservoir, we used the data of March 2014 and November 2015 as the stable period of cyanobacteria before and after projects respectively. Then we used the data of July 2014 and July 2015 as the blooming period of cyanobacteria before and after projects respectively (Fig. 6).

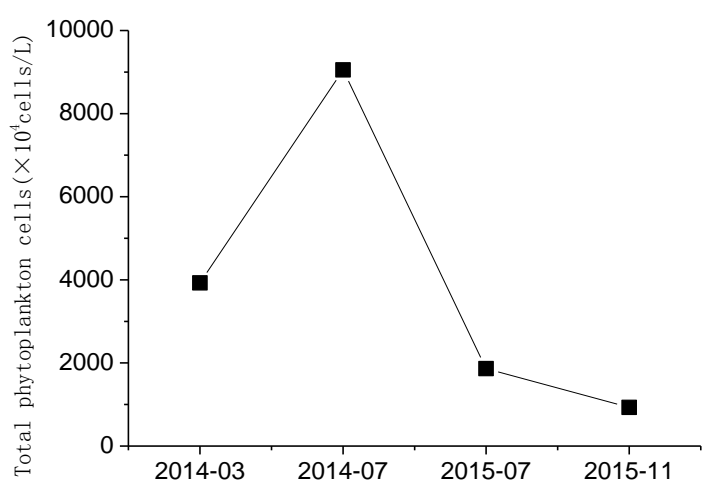

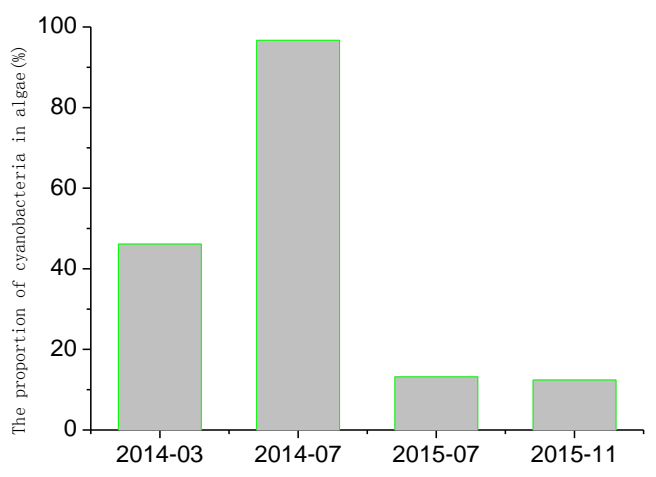

Figure 6. The total phytoplankton cells and the proportion of cyanobacteria in algae

The average algal cell density was $3927 \times 10^{4}$ cells/L, while the average cyanobacterial cell density occupied $46.13 \%$ in March 2014. The average algae cell density was $931 \times 10^{4}$ cells/L, where the average cyanobacterial cell density occupied $12.41 \%$ in November 2015 (Fig. 6). The total algal cell density decreased $76.3 \%$ and the cyanobacterial cell density decreased $93.6 \%$ before the ecological management.

The average algal cell density was $9051 \times 10^{4}$ cells $/ \mathrm{L}$, where the average cyanobacterial cell density occupied $96.69 \%$ in July 2014. The average algal cell density was $1865 \times 10^{4}$ cells/L, where he average cyanobacterial cell density occupied $13.2 \%$ in July 2015 (figure 6). The total algal cell density decreased $79.4 \%$ and the cyanobacterial cell density decreased $88.5 \%$ before the ecological management.

\section{Changes of Zooplankton}

Zooplankton could control the algal bloom, which cladocera was the important component to control cyanobacterial algae bloom. However, according to monitoring results before the reservoir ecological projects, 
there was no cladocera and the density and biomass of other zooplankton was low too. After ecological projects, cladocera had reproduced the Jiuquwan Reservoir. And other zooplankton, in particular, biological density and biomass of rotifers and copepods that be able to control the growth of algae also showed a significant increase (Fig. 7).
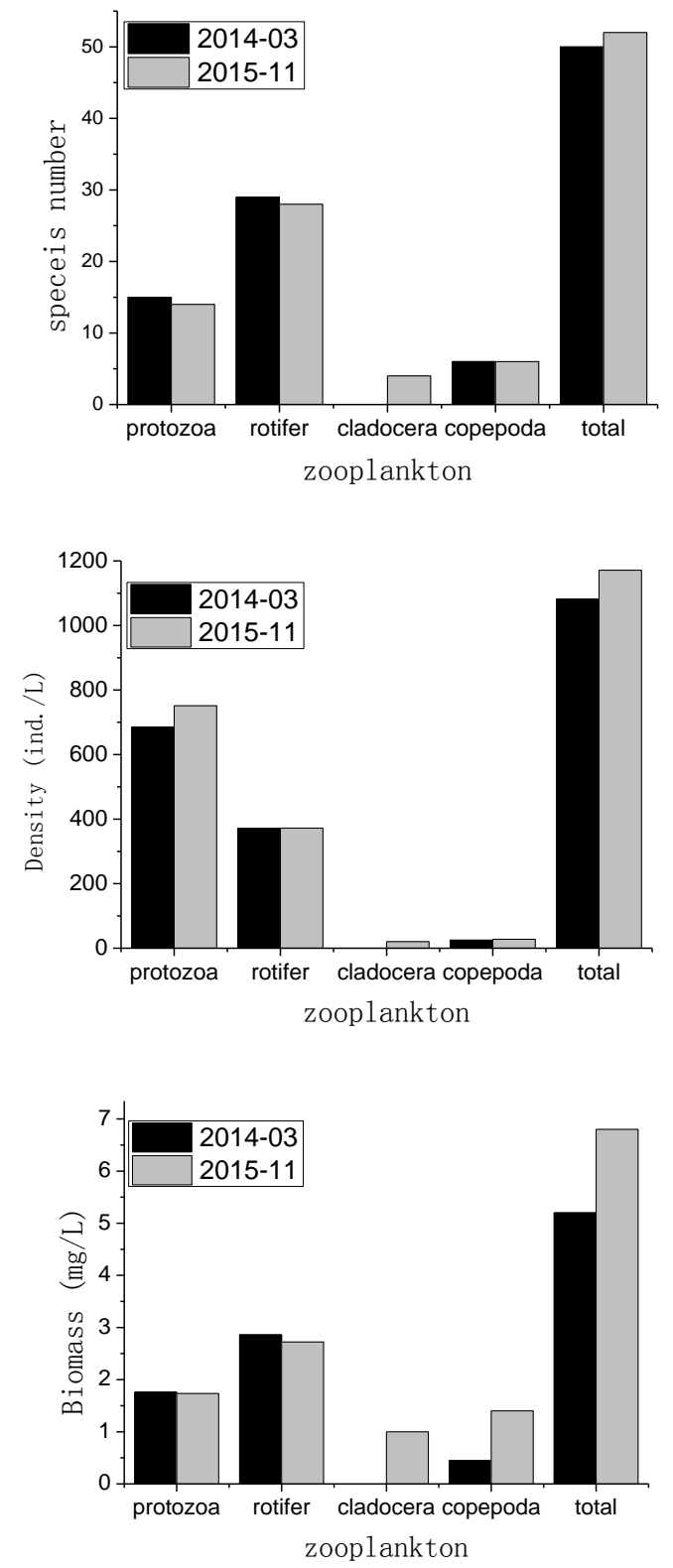

Figure 7. The change of zooplankton after ecological projects.

\section{Other Organisms}

The population the number of benthic fauna and fish had increased in the Jiuquwan Reservoir. Benthic animals, for example, chironomids and earthworm class were the mainly benthic animals before management projects in the reservoir. And then the main benthic fauna in the reservoir had become to Asian Clam and snails, which Asian Clam had been the former species after management projects in the reservoir.

\section{DISCUSSION}

Reservoir is a kind of semi artificial water body, the water dynamics is management by human beings. The process of eutrophication is more affected by human[6]. The aquatic vegetation coverage and water transparency increased, but mainly nutrient indicators and algae density decreased significantly after cyanobacteria bloom management projects in Jiuquwan Reservoir.

The ecological projects had successfully decreased the algae density and changed the structure of phytoplankton composition. The total density of phytoplankton cells decreased $76 \%$ to $88 \%$ than before, which cyanobacteria cell density decreased $88 \%$ to $98 \%$ than before. The aquatic plant and zooplankton biomass increased could control the species and biomass of phytoplankton. Through ecological projects submerged macrophytes could reduce phytoplankton through bottom-up effects and consequently promote clear water due to both direct and indirect suppression[7].The large-sized zooplankton increase the grazing pressure on phytoplankton, as has been evidenced in several studies by a major increase larger body size of cladocerans[8].

Species and total biomass of zooplankton significant changed after ecological projects and the total biomass of zooplankton increased significantly. Cladocera had been collected 4 species and its density and biomass had a certain proportion in total zooplankton. Copepod density did not change significantly, but its biomass increased significantly after management projects. The biomass of protozoa and rotifer did not change significantly after management projects. Species and total biomass of zooplankton maybe benefit from the increased of aquatic plant, especially the submerged macrophytes. Submerged macrophytes could offer shelter for zooplankton thus promote the species and biomass of zooplankton increased.

River corbicula and snails had increased significantly in Jiuquwan Reservoir. They had become the dominant species after ecological projects. Studies ever showed that benthic animals could significantly improve water quality[9]. As the species and biomass of benthic animals increased the reservoir nutrient and algae biomass would drop further.

Therefore, the effect of ecological control projects in Jiuquwan Reservoir to algae bloom is obviously. And within the management projects continue to play a role in Jiuquwan Reservoir the water nutrient content and the algae density will continue to fall. Zooplankton especially cladocera and copepod will continue to increase. The biodiversity of reservoir will increase and gradually formed a healthy reservoir ecosystem.

\section{ACKNOWLEDGEMENTS}

This project was supported by the Science and Technology Innovative Project of Water Resources of Guangdong Province, China (Grant No. 2014-12), the Natural Science Foundation of Guangdong Province, China (Grant No. 2015A030313866). 


\section{REFERENCES}

[1] Zhang Yayan, Zhixu Wu, Shujun Zhu. Model prediction of anabaena bloom using backward multiple regression between algae \& related environmental factors in Thousand-island Lake. Environmental Monitoring in China, 2002,25(3):37-41.

[2] Lu Kaihong, Weijin Yan, Shangan Su. Environmental and ecological engineering on control and remediation of eutrophicated water bodies: by using ameliorated alum plasma and fishes to control blue-green blooms of qiaodun reservoir. Acta Scientiae Circumstantiae, 2002,2(6):732-737.

[3] You Bin. Assessment on Present Situation for Sites of Drinking Water Sources at Nanwan Reservoir in Xinyang City and Countermeasures for Protection. Water Resources Protection,2001,4:45-47.

[4] Wang Zhaohui, Qiuqi Lin, Ren Hu, Chunlei Fan, Boping Han. Pollution by Blue-green Algae (Cyanophyta) in Reservoirs of Guangdong Province and Water Quality Evaluation. Journal of Tropical and Subtropical Botany, 2004,12(2):117-123.
[5] SuYuping, Yanfang Li, HouzhangZhong, Hui Lin, Ting Wang, Xuejing You. Recruitment of cyanobacteria from sediment of the Shanzai Reservoir. Acta Scientiae Circunstantiae, 2012,32(2):341-348.

[6] Lin Qiuqi, Boping Han. Reservoir limnology and its application in water quality management: An overview. Acta Ecologica Sinica, 2001, 21(6): 1034-1040.

[7] JeppesenE., M. Søndergaard, M. Søndergaard, and K. Christoffersen.The Structuring Role of Submerged Macrophytes in Lakes.1998. Springer, New York, USA.

[8] SøndergaardM., L. Liboriussen, A. R. Pedersen, and E. Jeppesen. Lake restoration by fish removal: Short- and long-term effects in 36 Danish lakes. Ecosystems, 2008, 11: 1291-1305.

[9] Weimin Quan, Xinqiang Shen, Lijiao Yan. Advances in research of biological purification of eutrophic water body. Chinese Journal of Applied Ecology, 2003, (11): 2057-2061. 